\title{
Changes in positive associations among vertebrate predators at South Georgia during winter
}

\author{
Samantha A. Monier ${ }^{1,2} \cdot$ Richard R. Veit ${ }^{1,2} \cdot$ Lisa L. Manne ${ }^{1,2}$
}

Received: 13 April 2019 / Revised: 8 July 2020 / Accepted: 14 July 2020 / Published online: 23 July 2020

(c) The Author(s) 2020

\begin{abstract}
We studied positive associations among seabirds and marine mammals at South Georgia on research cruises during the Austral winters of 1985, 1991 and 1993 and found statistically significant differences. We collected data on abundance and distribution, providing a critical reference for sub-Antarctic conservation in anticipation of future environmental changes. We found significant changes in the abundance of $29 \%$ of species surveyed and a consequent change in species diversity. We postulate that the resulting altered community composition may have previously unanticipated population effects on the component species, due to changes in positive interactions among species which use each other as cues to the presence of prey. We found a near threefold reduction in spatial overlap among vertebrate predators, associated with warming sea temperatures. As the strength and opportunity for positive associations decreases in the future, feeding success may be negatively impacted. In this way, environmental changes may disproportionately impact predator abundances and such changes are likely already underway, as Southern Ocean temperatures have increased substantially since our surveys. Of course the changes we describe are not solely due to changing sea temperature or any other single cause-many factors are important and we do not claim to have removed these from consideration. Rather, we report previously undocumented changes in positive associations among species, and argue these changes may continue into the future, given near-certain continued increases in climate-related changes.
\end{abstract}

Keywords Austral winter $\cdot$ Climate change $\cdot$ South Georgia $\cdot$ Seabirds $\cdot$ Local enhancement $\cdot$ Positive interactions

\section{Introduction}

Seabirds are important indicator species in marine ecosystems (Cairns 1987; Harding et al. 2007; Piatt et al. 2007; Gagne et al. 2018; Velarde et al. 2019); environmental change can propagate up the food web to impact top predators (Croxall et al. 2002; Colwell et al. 2012; Doney et al. 2012; Sydeman et al. 2017). Seabirds commonly feed in large multispecies groups of other birds, mammals, and

Electronic supplementary material The online version of this article (https://doi.org/10.1007/s00300-020-02720-4) contains supplementary material, which is available to authorized users.

Richard R. Veit

rrveit23@gmail.com

1 Biology Department, The Graduate Center, City University of New York, 365 th Avenue, New York, NY 10016, USA

2 Biology Department, College of Staten Island, 2800 Victory Blvd., Staten Island, NY 10314, USA fishes (Burger 1988; Harrison et al. 1991). Such associations have been shown to be both ubiquitous and stable (Veit and Harrison 2017), and thus likely important to local resource distribution and ecosystem structuring (Veit and Harrison 2017). Of immediate concern is that changing climate, either directly or indirectly, may be altering the number, composition, and quality of these multispecies feeding flocks (Bronstein 2015; Veit and Harrison 2017).

Antarctic krill-one of the main prey items of many seabirds (Croxall and Prince 1980, 1987; Harrison et al. 1991) have decreased as a result of climate and other anthropogenic changes such as increased harvesting (Loeb et al. 1997; Fraser and Hofman 2003; Atkinson et al. 2004; Flores et al. 2012; Atkinson et al. 2019). Declines of krill-feeding penguins are evident throughout West Antarctica and the Scotia Sea (Smith et al. 2003; Trathan et al. 2012). Similarly, the number of breeding female Antarctic fur seals (Arctocephalus gazellea) has declined at South Georgia, likely as a result of reduced krill availability (Forcada and Hoffman 2014). When the predictability of encountering prey is low, 
the foraging benefits associated with positive associations (Gotmark et al. 1986; Thiebault et al. 2014, 2016; Boyd et al. 2016b; McInnes et al. 2017; McInnes and Pistorius 2019) may be particularly important (Bairos-Novak et al. 2015).

Our paper focuses on interactions where predators use others as cues to the presence of prey. Aggregations of seabirds around krill swarms in the Southern Ocean may involve many thousands of individuals (Veit and Hunt 1991; Veit et al. 1993) that knowingly or unknowingly transmit information about where, what, and how to obtain food (Galef and Giraldeau 2001). Local enhancement (Thorpe 1956) may refer both to organisms cooperatively herding prey as well as passively producing cues (assemblages of predators in an otherwise unmarked at-sea landscape drawing the attention of other predators to a patch). Such interactions can be mutualistic with more than one participant benefiting $(+/+)$, facilitative/commensalistic where only a single participant derives direct benefits $(+/ 0)$, or antagonistic where one participant benefits at the expense of another (+/-) (Stachowicz 2001). It is extremely difficult to determine whether a seabird that joins a feeding flock experiences enhanced fitness due to food obtained at that flock. Nevertheless, we believe this must at least in part be true (see Gotmark et al. 1986; Grünbaum and Veit 2003; Thiebault et al. 2014; Boyd et al. 2016b; Thiebault et al. 2016; McInnes et al. 2017) and therefore feel it is justified to explore how positive interactions among marine predators may change as warming oceans alter species abundances. We broadly consider all positive interactions and this paper is not limited to any single definition of such behaviors. We do not attempt to identify what proportion of changes in positive associations are specifically caused by changing sea temperatures; however, as temperature has increased in the Scotia Sea and Antarctic Peninsula (Whitehouse et al. 2008), and will likely continue increasing, it seems prudent to draw attention to declines in interspecific associations which have the potential to exacerbate declines in individual species abundance (Bronstein 2015).

Changes in seabird abundance have been precipitated by changing climate in the California Current (Veit et al. 1996,
1997), the North Atlantic (Veit and Manne 2015), and the polar regions (Croxall et al. 2002; Jenouvrier et. al 2005a; Jenouvrier et al. 2005b; Descamps et al. 2017), among others (see Poloczanska et al. 2016 for a global report on climate-related changes across marine predators and their prey). Changes in seabird abundance are, of course, precipitated by numerous other inter-related factors such as ice cover, prey availability, and fishery mortality, which are exacerbated by rising temperatures (Croxall et al. 2002; Tuck et al. 2003; Robertson et al. 2014; Sydeman et al. 2015; Phillips et al. 2016; Pardo et al. 2017); strikingly, Paleczny et al. (2015) report a near 70\% decrease in the monitored seabird population worldwide from 1950 to 2010 . While such linkages between climate change and species abundance have been well established (Burger 1988; Croxall et al. 2002; Forcada et al. 2008; Doney et al. 2012; Boyd et al. 2016a), our paper additionally explores how changes in abundances may impact the number and quality of positive interactions among species (Janzen 1974, 1985; Terborgh 1986; Bronstein 2015; Veit and Harrison 2017). In seabirds, density of conspecifics has been found to be a better predictor of feeding than prey density (Grünbaum and Veit 2003; Thiebault et al. 2016); if a population drops below some abundance threshold, individuals from that population may no longer be present in large enough numbers to facilitate local enhancement, reducing the feeding success of those that previously benefited from such associations (McInnes et al. 2017; Fig. 1). The framework we present is one of "ecological" or "functional" extinction, where declines in abundances are severe enough such that species cease to perform their ecological roles (discussed in the context of marine ecosystems in McCauley et al. 2015). Implicit in this framework is that ecosystem functioning and services will also be lessened.

Predictions by Janzen (1974), Terborgh (1986), and Dakos and Bascompte (2014) about the potential fragility of mutualisms to anthropogenic change and the disruption of "keystone mutualisms" may already be underway in the Southern Ocean. Ocean warming in the Antarctic is most evident during the winter months in the Scotia Sea and in

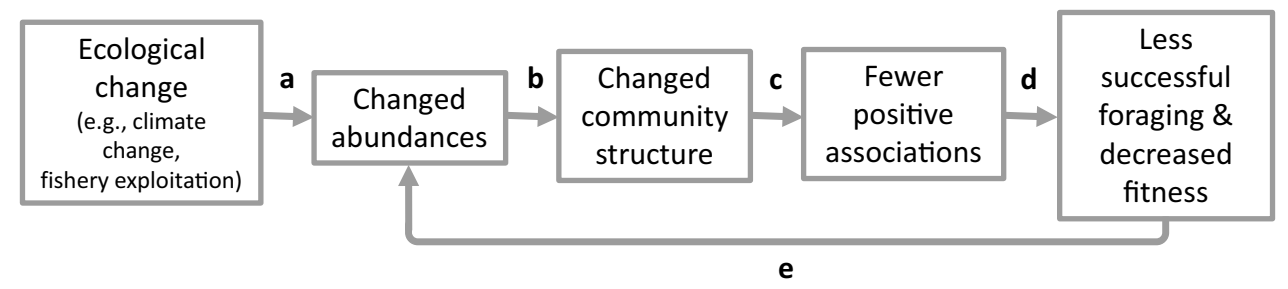

Fig. 1 Proposed drivers of change in foraging success. Changing species interactions may originally be driven by ecological change (linkages $\mathrm{a}$ and $\mathrm{b}$ ), but then the changed interactions themselves drive unexpectedly large changes in community structure (linkages $\mathrm{c}$ and d) and feeds back to change abundances (linkage e). Linkage e shows the breakdown of interspecific interactions accentuating the impacts of declining abundance-if a species has declined (either due to climate, prey availability or some other cause/combination of causes) then that decline may precipitate further decline due to loss of opportunities for positive interactions (i.e., facilitation and local enhancement) 
the west Antarctic waters surrounding South Georgia (Loeb et al. 1997; Smith et al. 2003; Whitehouse et al. 2008), a region with an exceptionally large and diverse seabird population (Croxall and Prince 1979). While several quantitative pelagic surveys of marine bird and mammal communities have been conducted at South Georgia during the summer months (Harrison et al. 1991; Hunt et al. 1992; Veit et al. 1993), to our knowledge, none have been conducted on nonbreeding winter populations (though see Jehl et al. (1979) for autumn surveys and Whitehouse and Veit 1994 for winter surveys off the Antarctic Peninsula). Global warming (accompanied by other anthropogenic changes) is rapidly altering the resource use and ranging patterns of a broad variety of species (Hickling et al. 2006; Chen et al. 2011; Langham et al. 2015; Poloczanska et al. 2016). Without proper knowledge of how things were, we are likely to inaccurately assess the state in which things are (Pauly 1995), thus, such records of predator prevalence are vital to conducting meaningful assessments of how climate change and human activity have impacted a region's community ecology.

We present the results from three research cruises during the winters of 1985, 1991 and 1993 off the east end of South Georgia. From these surveys we extracted abundances and conducted spatial analyses to test for evidence that changes in species abundance, regardless of underlying cause (e.g., climate, exploitation, ice extent), may have substantial community level effects. If this is true, then we expect (1) a decrease in spatial overlap associated with ecological change (Fig. 1 linkage c). At South Georgia, we expect this to be accompanied by (2) decreases in abundances associated with warming temperatures (Fig. 1 linkage a) and (3) changes in community composition, such as warm water species that do not breed at South Georgia moving in to feed on the South Georgia shelf as temperature increases (e.g., Hunt et al. 1992; Fig. 1 linkage b); hypotheses 2 and 3 serve to investigate temperature as a possible mechanism behind hypothesis 1 .

\section{Methods}

\section{Transect surveys}

We conducted transect surveys during three winters off the east end of South Georgia (Fig. 2). Two days of surveys were conducted in 1985, five in 1991, and six in 1993 (all survey dates fell between June 2 and July 2). In 1985 a single observer (R.R. Veit) watched from the bridge of the $\mathrm{R} / \mathrm{V}$ Polar Duke and all birds and marine mammals seen during 1 day's $300 \mathrm{~m}$ strip transect were summed by species. In 1991 and 1993 teams of two observers switched off watching and recording from within the pilothouse of the a
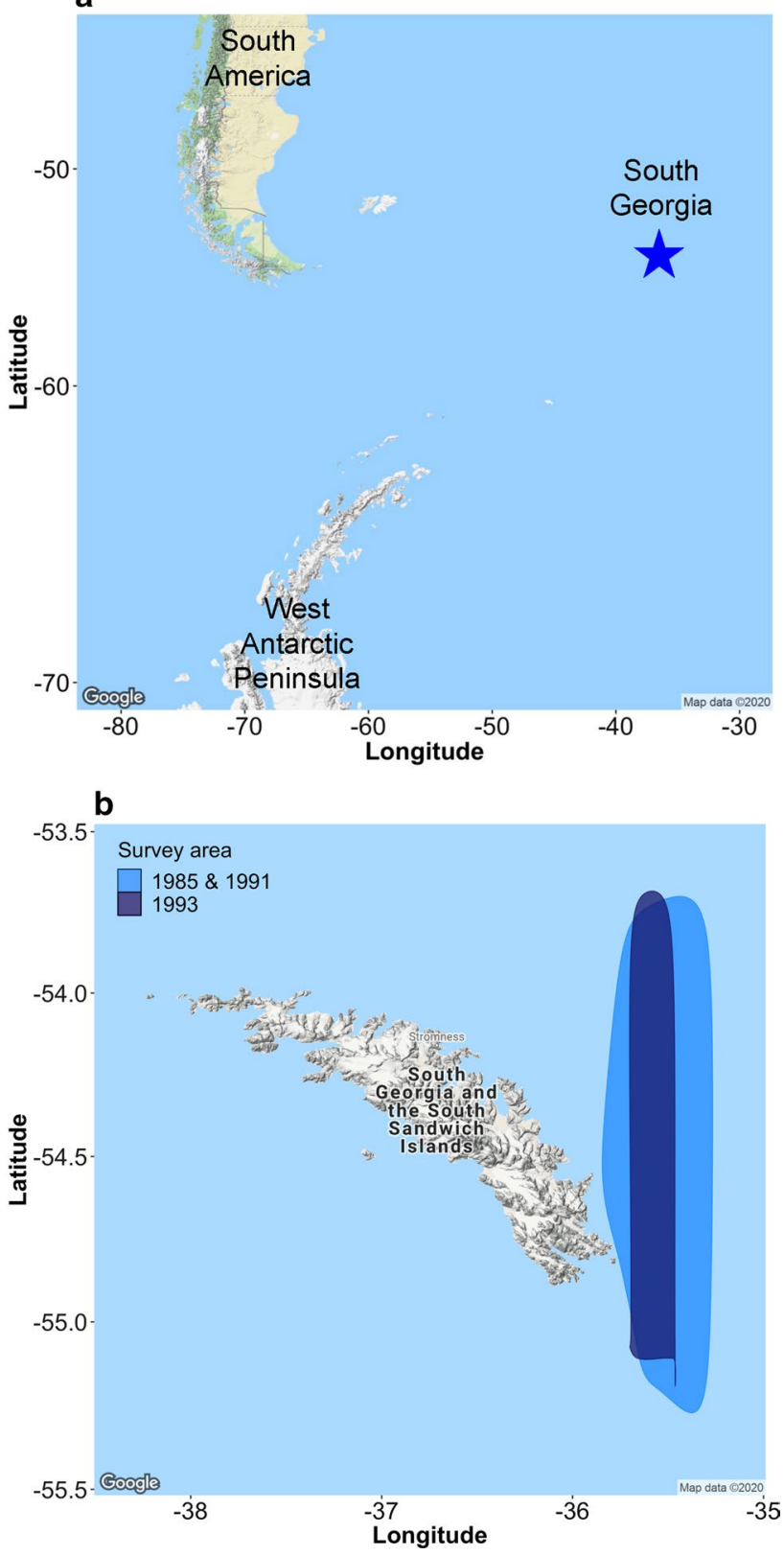

Fig. 2 Study area (base maps produced using the R package ggmap, Kahle and Wickham 2013) (a) South Georgia (starred) is located southeast of South America and northeast of the West Antarctic Peninsula. b Transect surveys were conduced off the east end of South Georgia in 1985, 1991 and 1993. Ship speed was equal in all years. In 1993 transects were repeated on multiple days

R/V Nathaniel Palmer on $300 \mathrm{~m}$ transects similar to those in 1985. This was standard procedure for shipboard seabird transects at the time (Tasker et al. 1984) as this was before the use of "distance sampling" (Buckland et al. 2001). There was never more than one person observing at any given time, but, to achieve consistency among observations, either Veit or seasoned seabird biologist Morgan was present in the 
pilothouse to supervise at all times when other observers collected data in 1991 and 1993. Ship-following birds were recorded only once when first noted. Data were collected during all weather conditions, but visibility was never below $500 \mathrm{~m}$ more than briefly. Ship speed was approximately 10 $\mathrm{kn}$, and each transect required all daylight hours (about $6 \mathrm{~h}$ ) to complete.

Three taxa not identified to species-unidentified giant petrels, diving petrels and prions-were incorporated into our species-level analyses because they were found to make up a substantial percentage of that category's sightings. For example, our analysis did not consider Northern and Southern Giant Petrels (Macronectes halli and Macronectes giganteus) separately because there were substantially more birds in the dataset classified as "unidentified giant petrel" than there were birds classified as either of the component species. We believe the vast majority of unidentified prions to be Antarctic Prions (Pachyptila desolatea) and virtually all diving petrels to be Common Diving Petrels (Pelecanoides urinatrix), based on birds that landed on the ship and identified in the hand. The remaining taxa not identified to species (unidentified penguin, unidentified albatross, unidentified prion/Blue Petrel and unidentified bird) were found to make up only a small percentage of their taxa's sightings (often $<1 \%$, never more than $7 \%$ ) and so were excluded from species-level analyses but included in broader analysis when stated. Common and Latin names of all species sighted are listed in Online Resource 1. Unless otherwise stated, for each day of survey, all sightings were summed and divided by transect length to obtain the number of individuals (birds or marine mammals) observed per kilometer.

\section{Spatial co-occurrence}

We used Recurrent Group Analysis (Fager 1957; Veit 1995) to identify statistically significant pairings of species for 1991 and 1993 (for 1985 the abundance data are only available as daily sums). To determine whether pairs of species co-occurred (i.e., interspecific associations) we divided the transects into $\sim 1$-h bins (equal to $\sim 18.5$ linear $\mathrm{km}$ ). If the distribution data (individuals $/ \mathrm{km}$ ) showed statistically significant overlap among bins, we considered those pairs of species co-occurring (Fager 1957; Veit 1995; Silverman and Veit 2001; Grünbaum and Veit 2003; Silverman et al. 2004). We determined for each pair of species whether the number of joint occurrences was significantly $(p<0.01)$ greater than would be expected given random association.

The value of recurrent group analysis for measuring interspecific association lies in its two-step implementation: first, groups of species that show non-random association on the basis of presence/absence data are identified, then abundance relationships among the species within the groups are calculated. Thus, recurrent group analysis avoids the ambiguity of interpreting negative correlations that are negative because the two species choose different habitats in which to search for food (Fager 1957; Veit 1995).

\section{Temperature}

Monthly sea surface temperature (SST) values were extracted from Meredith et al. (2008) using the program WebPlotDigitizer (https://automeris.io/WebPlotDigitizer/) and denormalized by adding the series mean and multiplying by the standard deviation. Data represent optimum interpolation SST from $53.51^{\circ} \mathrm{S}, 32.51^{\circ} \mathrm{W}$ (just north east of South Georgia) compiled from in situ and satellite SST. Mean temperatures during winter months (May-August, $n=4$ ) were as follows: The coldest year was $1991\left(-0.98^{\circ} \mathrm{C} \pm 0.07 \mathrm{SE}\right)$, the warmest year was $1993\left(0.63{ }^{\circ} \mathrm{C} \pm 0.1 \mathrm{SE}\right)$, and 1985 was an intermediate year $\left(-0.06^{\circ} \mathrm{C} \pm 0.16 \mathrm{SE}\right)$.

\section{Results}

\section{Spatial co-occurrence}

We found strong evidence of statistically positive association among species. Furthermore there was a substantial shift between 1991 and 1993 in the proportion of species found to be co-occurring. There were significantly fewer associations among possible taxonomic pairings in 1993 (13\% of 231 possible pairings) than in 1991 (36\% of 136 pairings) (Chi-square test, $X_{\mathrm{df}}=16.7, p<0.0001$ ). Example pairs of species strongly associated in 1991 but not 1993 can be seen in Fig. 3.

Our data revealed evidence of a decline in intraspecific associations as well. The average size of a single species aggregation was larger in 1991 than 1993. The mean aggregate size of the 1991 dataset (single species counts as they were reported by the observer) was $\sim 7$ individuals/aggregation (6.6 $\pm 0.44 \mathrm{SE}, n=4193)$. For comparison, in 1993 the mean aggregate size of the dataset was $\sim 2$ individuals/ aggregation $(1.8 \pm 0.06 \mathrm{SE}, n=3104)$.

The largest single species aggregations were also seen in 1991. Four aggregations each consisting of 500 individual diving petrels were sighted, as well as two aggregations of Cape Petrels (Daption capense) of the same size. In 1993 the largest single species aggregations all belonged to Blue Petrels (Halobaena caerulea), only involving 65, 50 and 50 individuals (a decrease from 1991 of 87-90\%).

\section{Relationship between temperature and abundances}

Our analyses are based on the sighting of 60,453 birds and seals over the three winters of data collection. Of the 24 total species observed across the three survey years, $38 \%$ were 

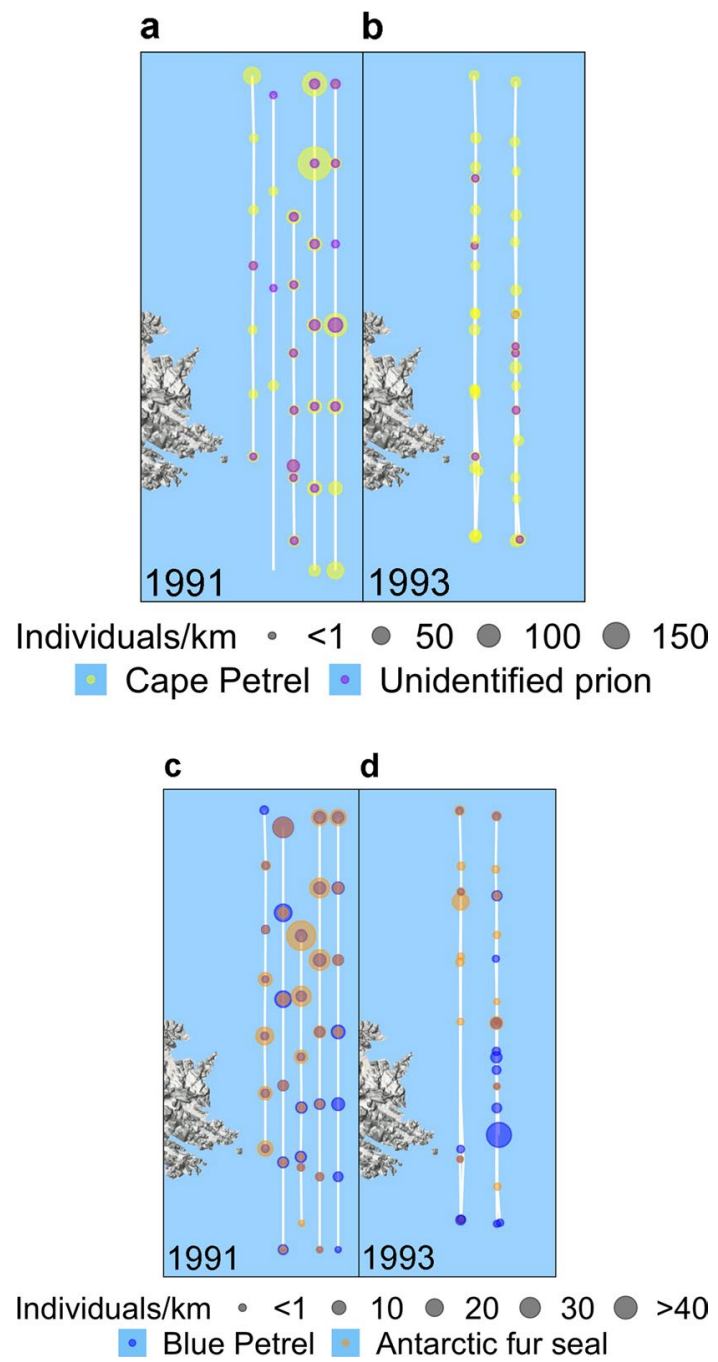

Fig. 3 Example pairs of bird and marine mammal species strongly associated in 1991 but not 1993 (base maps produced using the R package ggmap, Kahle and Wickham 2013). SST was warmer in 1993 than in 1991 and in 1993 there was also significantly less spatial overlap among species. Sampling effort was approximately equal between years: $35.5 \mathrm{~h}$ of observation in 1991 and $39.5 \mathrm{~h}$ of observation in 1993. Ship speed was also equal. In 1993 transects were repeated on multiple days. Transects (off the east end of South Georgia as shown in Fig. 2b) depicted in white, point colors made slightly transparent to show overlap. a In 1991 Cape Petrels and prions overlapped in 19 locations (56\% of bins) (b) in 1993 this decreased to 8 locations (22\% of bins). c In 1991 blue Petrels and Antarctic fur seals overlapped in 29 locations ( $85 \%$ of bins), $\mathbf{d}$ in 1993 they overlapped in 9 locations $(\sim 24 \%$ of bins $)$

absent from at least 1 year of surveys and 54\% never reached abundances $>1$ individual $/ \mathrm{km}$ (Figs. 4 and 5). Petrels as a group were the most sighted taxa (Figs. 4 and 5a), with Cape Petrels the most consistently abundant (Fig. 5a).

Individuals $/ \mathrm{km}$ was statistically similar between years (Kruskal-Wallis test, $H_{2}=2.1, p=0.3513$ ), however, a Dunn test on species by year revealed significant differences ( $p$-values corrected using the Bonferroni method, Fig. 4).
While the majority of species $(71 \%)$ had abundances that remained statistically similar across years ( $p>0.05$, Fig. 4a), significant differences were seen in select petrels and seals (Fig. 4b). Abundances of Antarctic Fulmars (Fulmarus glacialoides), prions, Kerguelen Petrels (Aphrodroma brevirostris), diving petrels, and Antarctic fur seals all exhibited negative relationships with temperature in at least one comparison (and no significant positive relationships). Snow Petrels (Pagodroma nivea) and Gray-headed Albatrosses (Thalassarche chrysostoma) were the only species to exhibit any statistically significant positive relationship with temperature (and displayed no significant negative relationships). Of these species that exhibited any significant change in abundance, four were most abundant in 1985 (an intermediate temperature).

In the coldest of the survey years we observed the fewest species while the most species were observed in the warmest year (17 species in 1991, 19 in 1985, 22 in 1993 Fig. 5a). Shannon-Wiener diversity (Zar 1999) was significantly different between years (ANOVA, $F_{2}=4.77, p=0.0351$ ). A post hoc Tukey-Kramer revealed significant differences between the warmest (1993) and coldest (1991) years $(p=0.044)$ (Fig. 5b).

\section{Changes in abundance by habitat type}

Habitat (warm water species of the sub-Antarctic or cold warm species of the high-Antarctic) was determined based on range maps in Brooke (2004) and Harrison (1987) (See Online Resource 1 for each species' habitat classification). The relationship between temperature and abundance does not appear to be habitat dependent (Table 1) - high-Antarctic species were not more likely to decline with increasing SST and sub-Antarctic birds were not more likely to increase.

\section{Discussion}

Our study supports our prediction that changed abundances can lead to reduced interspecific associations. There was a near threefold reduction in the number of significant species associations between the coldest and warmest years (1991 and 1993). The inference from this finding is that environmental change may precipitate changes in foraging success, especially negative ones, that could cause nonlinear effects above and beyond simple declines in abundance (Fig. 1).

To investigate Fig. 1 linkages $\mathrm{c}$ and d, we needed to establish whether the spatial association among foragers who use each other as cues to prey (Harrison et al. 1991; Tremblay et al. 2014; Veit and Harrison 2017) had changed, as this is a prerequisite to asking whether the selective benefit of the association has changed (analogous changes have been 

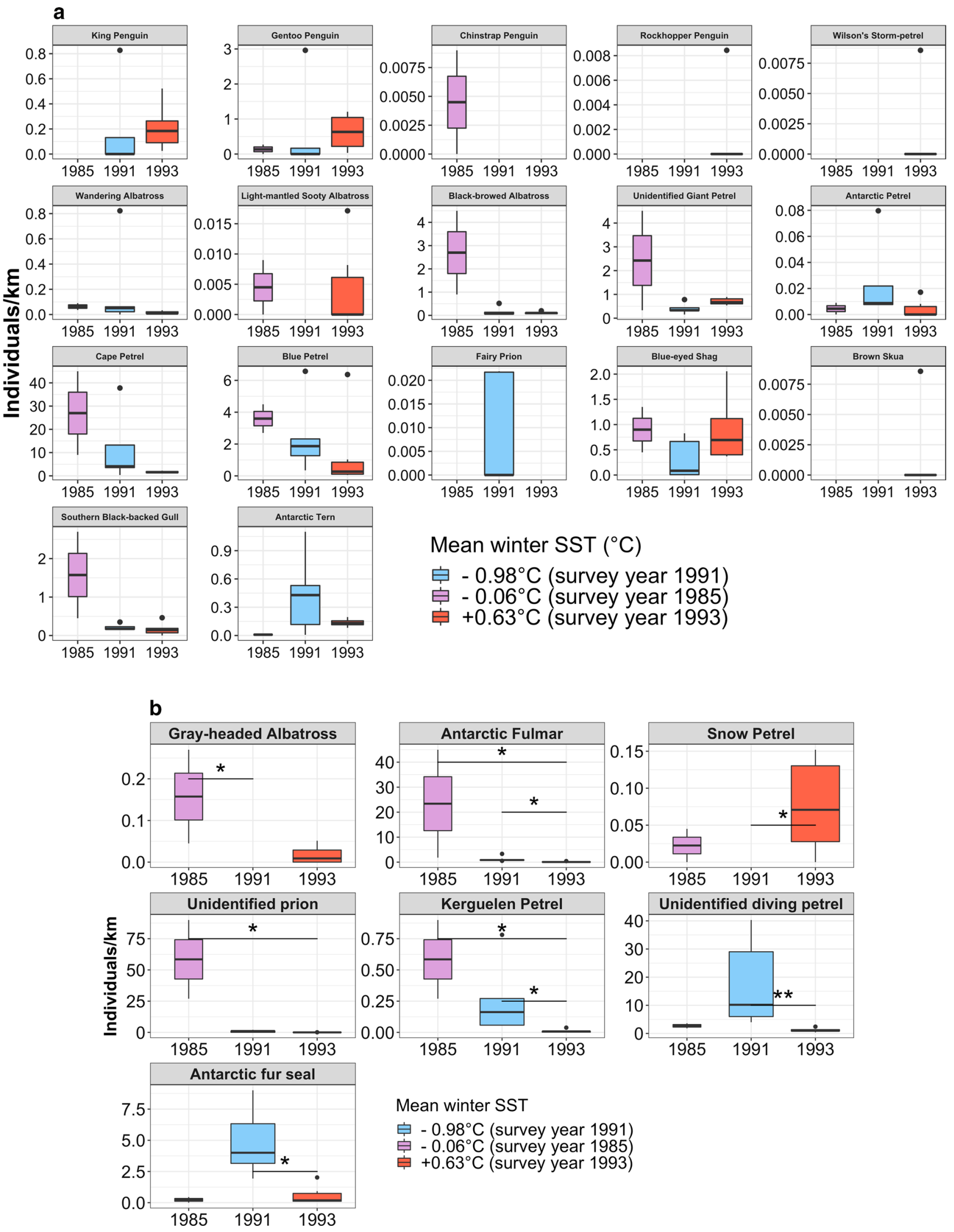

Mean winter SST

追 $-0.98^{\circ} \mathrm{C}$ (survey year 1991)

追 $-0.06^{\circ} \mathrm{C}$ (survey year 1985 )

官 $+0.63^{\circ} \mathrm{C}$ (survey year 1993) 
4Fig. 4 Changes in abundance across survey years and SST. Plot colors correspond to SST with red being the warmest survey year, blue being the coldest and purple corresponding to an intermediate temperature (standard errors and sample sizes for mean winter temperatures are given in "Methods"). Phylogeny and common names taken from Dickinson and Remsen (2013). Note each plot has a unique $y$-axis scale. Width of the boxes proportional to the square root of the sample size. a Species whose abundance did not significantly change between years/with temperature (b) species exhibiting significant changes in abundance between survey years. The length of the annotated line indicates which years the significant comparison is between. Significance levels indicated by $* p<0.05$ and $* * p<0.01$

reported for systems of pollinators, Winfree et al. 2014). Pelagic communities of seabirds are assemblages of species that occur together within the same marine habitat (Pocklington 1979; Briggs et al. 1987; Ribic and Ainley 1989; Wahl et al. 1989); if such assemblages were a random mix of species each pursuing prey independently, then the spatial distribution of each species would be independent of others. In contrast, the benefits associated with positive interactions should be associated with a highly connected network (Thébault and Fontaine 2010). As co-occurrence (statistical overlap) is an index of the use of local enhancement or facilitation (Veit and Harrison 2017), the change we witnessed is consistent with our prediction that changes in abundances could have disproportionate impacts upon feeding success of the component species.

Positive interspecific associations are the products of their community (characteristic combinations of species and their relative abundances, Veit and Harrison 2017). Different species of seabirds may constitute "behavioral phenotypes" as they join feeding flocks at different stages of their formation and exhibit different feeding strategies. The net result is that more prey gets captured per group member. Thus, it may be important to conserve groups of species that facilitate one another as units of biodiversity (Greggor et al. 2017). Furthermore, communities that are more behaviorally heterogeneous may occupy a greater diversity of niches and could thus be buffered against environmental change (Brown 2013).

Reliance on others for prey capture success may put such social species disproportionately at risk to declines in biodiversity (Veit and Harrison 2017), an idea supported by simulations run by Dakos and Bascompte (2014) which suggested mutualistic networks run a high risk of experiencing a tipping point: exposure to a gradual weakening of mutualistic strength caused abrupt onset community collapse in all 79 of their simulated plant/pollinator or plant/seed disperser communities; specialists were generally the first to collapse. Such a result may hold true for intraspecific positive associations as well: Grünbaum and Veit (2003) found that albatross density at South Georgia had a higher impact on feeding rate than did prey density, indicating, first, the importance of local enhancement (albatrosses responding to albatrosses) and second, that at low densities local enhancement may not be effective.

Any alteration to a species' habitat has the potential to disrupt social networking and thus, how animals obtain and transfer information (Greggor et al. 2016, 2017). The need to use local enhancement may depend on the abundance and type of prey available (Bairos-Novak et al. 2015), which may vary predictively between seasons but unpredictably between years (Murphy et al. 1998). Such associations may be particularly beneficial during times of stress, as positive interactions may stabilize a community (Stachowicz 2001; Bruno et al. 2003). The benefits of positive associations have been demonstrated both in theory (see simulations run by Boyd et al. 2016b) and experimentally (Gotmark et al. 1986). A formative study by Thiebault et al. (2014) showed that wild Cape Gannets (Morus capensis) that made use of social information substantially reduced their search time (a proxy for feeding success). Additionally, McInnes et al. (2017) showed catch-per-unit-effort increased during group versus solitary foraging wild African penguins (Spheniscus demersus). Key questions still remain, however, as to the direct benefits positive associations may offer (such as access to better quality patches, increased prey intake, or offspring survival) especially in regards to interspecific associations.

Importantly, some species/individuals might serve as more conspicuous cues than others (due to coloration or body size, Bretagnolle 1993; Silverman et al. 2004; Bairos-Novak et al. 2015) or may be a preferred cue (due to dietary overlap between the flock initiator and flock joiner or because of the initiator's patch-finding aptitude). Whether these associations are obligate or merely opportunistic (Bronstein 2015), it suggests important fitness consequences for the evolution of coexisting species and their interdependence (Bretagnolle 1993; Laland et al. 1999; Laland and Boogert 2008).

We provide an example of how continued environmental change (e.g., expected temperature increases) may impact foraging success via changes in positive interactions. Of immediate concern is that changing climate can change the abundances of those engaged in multispecies feeding flocks, and indeed the nature of interactions among species previously engaged in mutually positive associations can change (Janzen 1974; Terborgh 1986; Bronstein 2015; Anguita and Simeone 2016), leading to faster/larger declines than may have otherwise been predicted (Fig. 1 linkage e).

Contrary to our predictions, abundances of most species did not decrease as temperatures increased. However, $21 \%$ of the 24 the species sighted exhibited negative relationships with temperature in at least one comparison. These changes were seen in select species of petrels and fur seals. The remaining taxa (gulls and terns, penguins, shags, and skuas) all exhibited relatively low abundances 

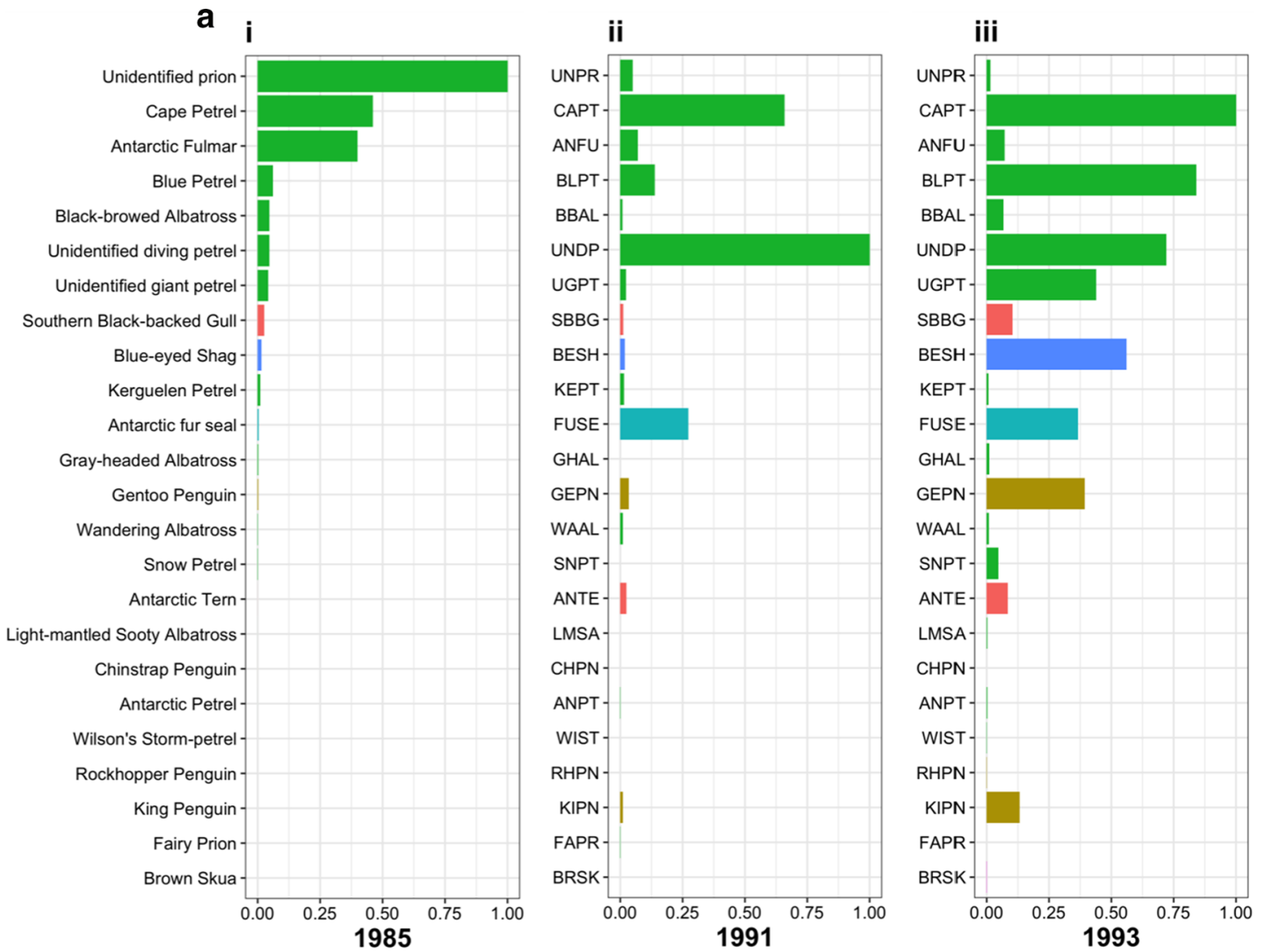

Proportional abundance

penguins petrels shags skuas seals

b

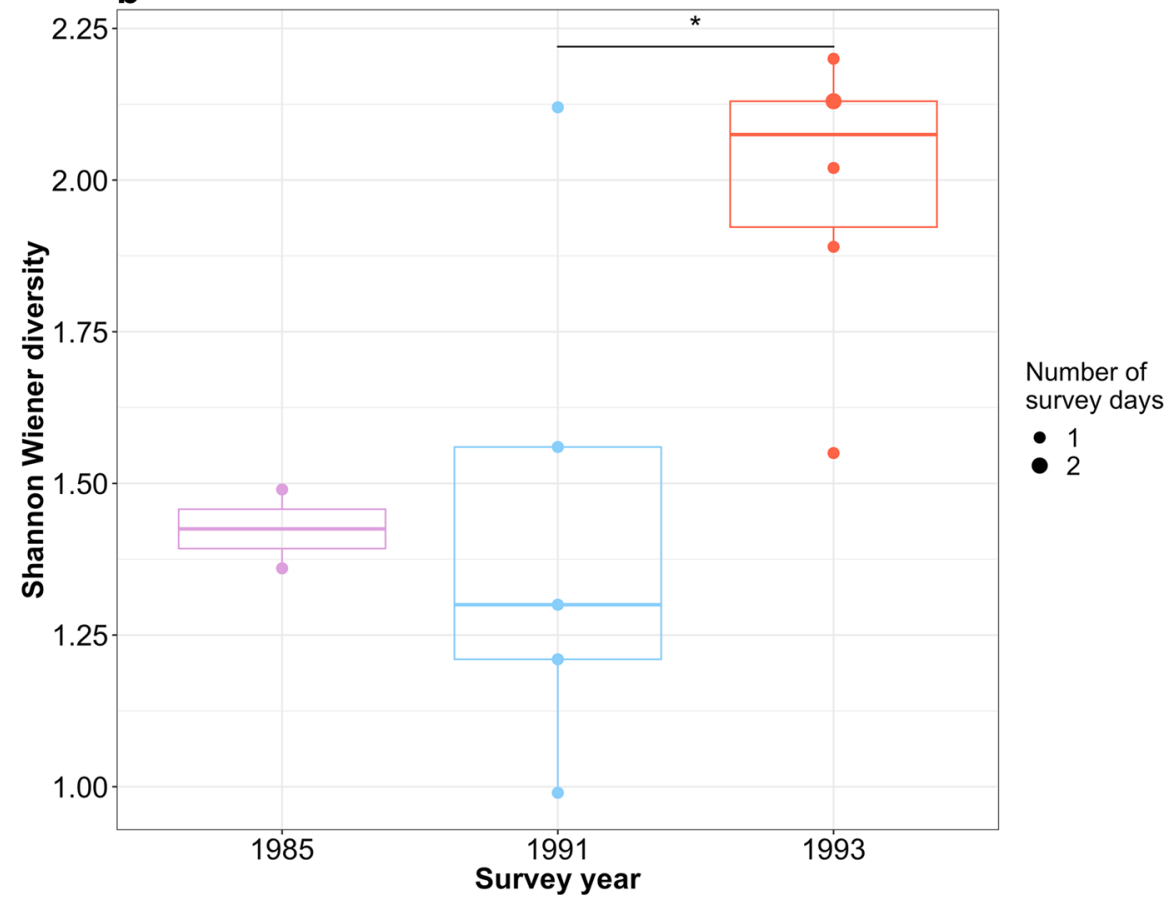


४Fig. 5 Community change over time. a Yearly average individuals/ $\mathrm{km}$, standardized against the highest average value for the given year. Species ordered highest to lowest based on 1985 abundances. b Shannon Wiener diversity calculated based on daily individual $/ \mathrm{km}$ values (using the R package vegan, Oksanen et al. 2019). Boxplot overlaid on top of these daily values. Color-coding and significance annotations as in Fig. 4

across the three survey years (Fig. 4). Fifty-four \% of all species never reached abundances $>1$ individual $/ \mathrm{km}$ (Fig. 4) suggestive of a possible floor effect, where we do not see many significant declines in abundances because abundances are all low to begin with. Additionally, the difference between our coldest and warmest survey year's mean winter temperature was $\sim 1.6{ }^{\circ} \mathrm{C}$, but there is substantial evidence showing the waters around South Georgia have warmed since then and will continue to warm (Whitehouse et al 2008; Boyd et al. 2016a). Thus, it is possible some of our species' climate envelopes have shifted since our data were collected.

Regardless of what percentage of the species exhibited changed abundances, and regardless of the mechanism (be it temperature change or some other factor), the changes in abundances witnessed were sufficient to produce significant changes to the community (Fig. 5).

Contrary to our predictions, high-Antarctic species were not more than likely to decline with increasing SST and subAntarctic birds were not more likely to increase. In fact, the only species to exhibit significant positive relationships with temperature were cold water birds: Gray-headed Albatrosses (cf. Ryan 2018 and Poncet et al. 2017) and Snow Petrels (Fig. 4). Both of these species are known to associate with ice flows, Snow Petrels obligatorily so (Brooke 2004). In warm years sea ice often pushes farther north (Turner et al. 2016) into the sub-Antarctic, and this may in part account for the responses by these species. The majority of species exhibited no significant changes in abundance between years, regardless of oceanographic habitat (Fig. 4, Table 1). Still, however, significant changes to community composition were found (Fig. 5).
Table 1 Number of species that exhibited decreased, increased, or non-significant changes in abundance ( $p<0.05$, see Fig. 4 ) by habitat. (a) Changes between years where SST decreased (1985-1991), (b) changes between years where SST increased (1985-1993 and 19911993)

\begin{tabular}{llll}
\hline Habitat & $\begin{array}{l}\text { Decreasing } \\
\text { species }\end{array}$ & Increasing species & No change \\
\hline Colder water & 1 & 1 & 11 \\
Warmer water & 0 & 0 & 9 \\
\hline (b) & & & \\
\hline Colder water & 3 & 1 & 9 \\
Warmer water & 2 & 0 & 7 \\
\hline
\end{tabular}

\section{Conclusions}

Figure 1 linkages $\mathrm{a}$ and $\mathrm{b}$ are well established (Burger 1988; Veit et al. 1996, 1997; Croxall et al. 2002; Jenouvrier et al. 2005a, b; Forcada et al. 2008; Doney et al. 2012; Veit and Manne 2015; Boyd et al. 2016a). The point of this study, however, is (1) the novel establishment of linkage $\mathrm{c}$-changes in the community resulting in changed species interactions and (2) the presentation of a framework for how continued environmental change (e.g., expected temperature increases, Fig. 1 linkage a) may impact fitness and feedback to alter future abundances via said changed species interactions (Fig. 1 linkages d and e). Our study highlights such changes within a winter community (although changes to the community between seasons has previously been shown to coincide with changed species interactions, Anguita and Simeone 2016). Of course, many factors besides SST are important and we do not claim to have removed these from consideration. Rather, the framework we present highlights the expediency of incorporating behavioral data into conservation decisions, consistent with recent suggestions by behavioral ecologists (Blumstein and Fernandez-Juricic 2010; Camphuysen et al. 2012; Bronstein 2015; Greggor et al. 2016, 2017). 
Acknowledgements We acknowledge support from the National Science Foundation DPP-8918130 to P.M. Kareiva and R.R. Veit and thank I.W.D. Dalziel for the invitation to join the 1985 expedition. We would like to thank all those involved in the surveys including C. Cinninger, D.F. Doak, A. Engh, S.F. Heppell, M. Hollon, C.E. Jordan, R.A. Morgan, W.F. Morris, G.A. Nevitt and G.T. Smith. We thank M.P. Meredith for providing helpful information, and the three anonymous reviewers for their feedback.

\section{Compliance with ethical standards}

Conflict of interest The authors declare that they have no conflict of interest.

Open Access This article is licensed under a Creative Commons Attribution 4.0 International License, which permits use, sharing, adaptation, distribution and reproduction in any medium or format, as long as you give appropriate credit to the original author(s) and the source, provide a link to the Creative Commons licence, and indicate if changes were made. The images or other third party material in this article are included in the article's Creative Commons licence, unless indicated otherwise in a credit line to the material. If material is not included in the article's Creative Commons licence and your intended use is not permitted by statutory regulation or exceeds the permitted use, you will need to obtain permission directly from the copyright holder. To view a copy of this licence, visit http://creativecommons.org/licenses/by/4.0/.

\section{References}

Anguita C, Simeone A (2016) The shifting roles of intrinsic traits in determining seasonal feeding flock composition in seabirds. Behav Ecol 27:501-511. https://doi.org/10.1093/beheco/arv180

Atkinson A, Siegel V, Pakhomov E, Rothery P (2004) Long-term decline in krill stock and increase in salps within the Southern Ocean. Nature 432:100-103. https://doi.org/10.1038/nature02996

Atkinson A, Hill SL, Pakhomov EA, Siegel V, Reiss CS, Loeb VJ, Steinberg DK, Schmidt K, Tarling GA, Gerrish L, Sailley SF (2019) Krill (Euphausia superba) distribution contracts southward during rapid regional warming. Nat Clim Change 9:142-147. https ://doi.org/10.1038/s41558-018-0370-z

Bairos-Novak KR, Crook KA, Davoren GK (2015) Relative importance of local enhancement as a search strategy for breeding seabirds: an experimental approach. Anim Behav 106:71-78. https://doi. org/10.1016/j.anbehav.2015.05.002

Blumstein DT, Fernandez-Juricic E (2010) A primer of conservation behavior. Sinauer Associates, Sunderland

Boyd PW, Cornwall CE, Davison A, Doney SC, Fourquez M, Hurd CL, Lima ID, McMinn A (2016a) Biological responses to environmental heterogeneity under future ocean conditions. Glob Change Biol 22:2633-2650. https://doi.org/10.1111/gcb.13287

Boyd C, Grünbaum D, Hunt GL Jr, Punt AE, Weimerskirch H, Bertrand S (2016b) Effectiveness of social information used by seabirds searching for unpredictable and ephemeral prey. Behav Ecol 27:1223-1234. https://doi.org/10.1093/beheco/arw039

Bretagnolle V (1993) Adaptive significance of seabird coloration: the case of procellariiforms. Am Nat 142:141-173. https://doi. org $/ 10.1086 / 285532$

Briggs KT, Tyler WB, Lewis DB, Carlson DR (1987) Bird communities at sea off California: 1975 to 1983. Stud Avian Biol 11: 1-74

Bronstein JL (ed) (2015) Mutualism, 1st edn. Oxford University Press, New York
Brooke ML (2004) Albatrosses and petrels across the world. Oxford University Press, Oxford

Brown RL (2013) Learning, evolvability and exploratory behaviour: extending the evolutionary reach of learning. Biol Philos 28:933-955. https://doi.org/10.1007/s10539-013-9396-9

Bruno JF, Stachowicz JJ, Bertness MD (2003) Inclusion of facilitation into ecological theory. Trends Ecol Evol 18:119-125. https ://doi.org/10.1016/S0169-5347(02)00045-9

Buckland ST, Anderson DR, Burnham KP, Laake JL, Borchers DL, Thomas L (2001) Introduction to distance sample: Estimating abundances of biological populations. Oxford University Press, Oxford

Burger J (1988) Seabirds and other marine vertebrates: competition, predation and other interactions. Columbia University Press, New York

Cairns DK (1987) Seabirds as indicators of marine food supplies. Biol Oceanogr 5:261-271. https://doi.org/10.1080/01965 581.1987.10749517

Camphuysen KCJ, Shamoun-Baranes J, Bouten W, Garthe S (2012) Identifying ecologically important marine areas for seabirds using behavioural information in combination with distribution patterns. Biol Conserv 156:22-29. https://doi.org/10.1016/j. biocon.2011.12.024

Chen IC, Hill JK, Ohlemüller R, Roy DB, Thomas CD (2011) Rapid range shifts of species associated with high levels of climate warming. Science 333:1024-1026. https://doi.org/10.1126/scien ce. 1206432

Colwell RK, Dunn RR, Harris NC (2012) Coextinction and persistence of dependent species in a changing world. Annu Rev Ecol Evol Syst 43:183-203. https://doi.org/10.1146/annurev-ecols ys-110411-160304

Croxall JP, Prince PA (1979) Antarctic seabirds and seal monitoring studies. Polar Rec 19:573-595. https://doi.org/10.1017/S0032 247400002680

Croxall JP, Prince PA (1980) Food, feeding ecology and ecological segregation of seabirds at South Georgia. Biol J Linn Soc 14:103-131. https://doi.org/10.1111/j.1095-8312.1980.tb001 $01 . \mathrm{x}$

Croxall JP, Prince PA (1987) Diet and feeding ecology of Procellariiformes. In: Seabirds Croxall JP (ed) Feeding ecology and role in marine ecosystems. Cambridge University Press, Cambridge, pp 135-171

Croxall JP, Trathan PN, Murphy EJ (2002) Environmental change and Antarctic seabird populations. Science 297:1510-1515. https:// doi.org/10.1126/science.1071987

Dakos V, Bascompte J (2014) Critical slowing down as early warning for the onset of collapse in mutualistic communities. Proc Natl Acad Sci 111:17546-17551. https://doi.org/10.1073/pnas.14063 26111

Descamps S, Aars J, Fuglei E, Kovacs KM, Lydersen C, Pavlova O, Pedersen AØ, Ravolainen V, Strøm H (2017) Climate change impacts on wildlife in a High Arctic archipelago-Svalbard, Norway. Glob Change Biol 23:490-502. https://doi.org/10.1111/ gcb.13381

Dickinson EC, Remsen JV (2013) The Howard and Moore complete checklist of birds of the world, Volume 1, Non-passerines, vol 4. Aves Press, Eastbourne

Doney SC, Ruckelshaus M, Emmett Duffy J, Barry JP, Chan F, English CA, Galindo HM, Grebmeier JM, Hollowed AB, Knowlton N, Polovina J, Rabalais NN, Sydeman WJ, Talley LD (2012) Climate change impacts on marine ecosystems. Ann Rev Mar Sci 4:11-37. https://doi.org/10.1146/annurev-marine-041911-111611

Fager EW (1957) Determination and analysis of recurrent groups. Ecology 38:586-595. https://doi.org/10.2307/1943124

Flores H, Atkinson A, Kawaguchi S, Krafft BA, Milinevsky G, Nicol S, Reiss C, Tarling GA, Werner R, Bravo Rebolledo E, Cirelli 
V, Cuzin-Roudy J, Fielding S, Groeneveld JJ, Haraldsson M, Lombana A, Marschoff E, Meyer B, Pakhomov EA, Rombolá E, Schmidt K, Siegel V, Teschke M, Tonkes H, Toullec JY, Trathan PN, Tremblay N, Van de Putte AP, van Franeker JA, Werner T (2012) Impact of climate change on Antarctic krill. Mar Ecol Prog Ser 458:1-19. https://doi.org/10.1073/pnas.1810141115

Forcada J, Hoffman JI (2014) Climate change selects for heterozygosity in a declining fur seal population. Nature 511:462-465. https:// doi.org/10.1038/nature13542

Forcada J, Trathan PN, Murphy EJ (2008) Life history buffering in Antarctic mammals and birds against changing patterns of climate and environmental variation. Glob Change Biol 14:2473-2488. https://doi.org/10.1111/j.1365-2486.2008.01678.x

Fraser WR, Hofmann EE (2003) A predator's perspective on causal links between climate change, physical forcing and ecosystem response. Mar Ecol Prog Ser 265:1-15. https://doi.org/10.3354/ meps 265001

Gagne TO, David Hyrenbach K, Hagemann ME, Van Houtan KS (2018) Trophic signatures of seabirds suggest shifts in oceanic ecosystems. Sci Adv 4:eaao3946. https://doi.org/10.1126/sciad v.aao3946

Galef BG, Giraldeau L-A (2001) Social influences on foraging in vertebrates: causal mechanisms and adaptive functions. Anim Behav 61:3-15. https://doi.org/10.1006/anbe.2000.1557

Gotmark F, Winklet DW, Malte A (1986) Flock-feeding on fish schools increases individual success in gulls. Nature 324:698-699. https ://doi.org/10.1038/320129a0

Greggor AL, Berger-Tal O, Blumstein DT, Angeloni L, Bessa-Gomes C, Blackwell BF, St Clair CC, Crooks K, de Silva S, FernándezJuricic E, Goldenberg SZ, Meznick SL, Owen M, Price CJ, Saltz D, Schell CJ, Suarez AV, Swaisgood RR, Winchell CS, Sutherland WJ (2016) Research priorities from animal behaviour for maximizing conservation progress. Trends Ecol Evol 31:953-964. https://doi.org/10.1016/j.tree.2016.09.001

Greggor AL, Thornton A, Clayton NS (2017) Harnessing learning biases is essential for applying social learning in conservation. Behav Ecol Sociobiol 71:16. https://doi.org/10.1007/s0026 5016-2238-4

Grünbaum D, Veit RR (2003) Black-browed albatrosses foraging on Antarctic krill: density-dependence through local enhancement? Ecology 84:3265-3275. https://doi.org/10.1890/01-4098

Harding AMA, Piatt JF, Schmutz JA (2007) Seabird behavior as an indicator of food supplies: sensitivity across the breeding season. Mar Ecol Prog Ser 352:269-274. https://doi.org/10.3354/meps0 7072

Harrison P (1987) Seabirds of the world: a photographic guide. Christopher Helm, London

Harrison NM, Whitehouse MJ, Heinemann D, Prince PA, Hunt GL Jr, Veit RR (1991) Observations of multispecies seabird flocks around South Georgia. Auk 108:801-810

Hickling R, Roy DB, Hill JK, Fox R, Thomas CD (2006) The distributions of a wide range of taxonomic groups are expanding polewards. Glob Change Biol 12:450-455. https://doi.org/10.11 11/j.1365-2486.2006.01116.x

Hunt GL Jr, Priddle J, Whitehouse MJ, Veit RR (1992) Changes in seabird species abundance near South Georgia during a period of rapid change in sea surface temperature. Antarct Sci 4:15-22. https://doi.org/10.1017/S0954102092000051

Janzen DH (1974) The deflowering of Central America. Nat Hist $83: 48-53$

Janzen DH (1985) The natural history of mutualisms. In: Boucher DH (ed) The biology of mutualisms: Ecology and evolution. Oxford University Press, New York, pp 40-99

Jehl JR, Todd FJS, Rumboll MA, Schwartz D (1979) Pelagic birds in the South Atlantic Ocean and at South Georgia in the austral autumn. Le Gerfaut 69:13-27
Jenouvrier S, Barbraud C, Weimerskirch H (2005a) Long-term contrasted responses to climate of two Antarctic seabird species. Ecology 86:2889-2903. https://doi.org/10.1890/05-0514

Jenouvrier S, Weimerskirch H, Barbraud C, Park Y-H, Cazelles B (2005b) Evidence of a shift in the cyclicity of Antarctic seabird dynamics linked to climate. Proc R Soc B 272:887-895. https:// doi.org/10.1098/rspb.2004.2978

Kahle D, Wickham H (2013) ggmap: spatial visualization with ggplot2. R J 5:144-161. https://doi.org/10.32614/RJ-2013-014

Laland KN, Boogert NJ (2008) Niche construction, co-evolution and biodiversity. Ecol Econ 69:731-736. https://doi.org/10.1016/j. ecolecon.2008.11.014

Laland KN, Odling-Smee FJ, Feldman MW (1999) Evolutionary consequences of niche construction and their implications for ecology. Proc Natl Acad Sci USA 96:10242-10247. https://doi. org/10.1073/pnas.96.18.10242

Langham GM, Schuetz JG, Distler T, Soykan CU, Wilsey C (2015) Conservation status of North American birds in the face of future climate change. PLoS ONE 10:e0135350. https://doi.org/10.1371/ journal.pone. 0135350

Loeb V, Siegel V, Holm-Hansen O, Hewitt R, Fraser W, Trivelpiece W, Trivelpiece S (1997) Effects of sea-ice extent and krill or salp dominance on the Antarctic food web. Nature 387:897-900. https ://doi.org/10.1038/43174

McCauley DJ, Pinsky ML, Palumbi SR, Estes JA, Joyce FH, Warner RR (2015) Marine defaunation: animal loss in the global ocean. Science 347:1255641. https://doi.org/10.1126/science.1255641

McInnes AM, McGeorge C, Ginsberg S, Pichegru L, Pistorius PA (2017) Group foraging increases foraging efficiency in a piscivorous diver, the African penguin. R Soc Open Sci 4:170918. https ://doi.org/10.1098/rsos.170918

McInnes AM, Pistorius PA (2019) Up for grabs: Prey herding by penguins facilitates shallow foraging by volant seabirds. R Soc Open Sci 6:190333. https://doi.org/10.1098/rsos.190333

Meredith MP, Murphy EJ, Hawker EJ, King JC, Wallace MI (2008) On the interannual variability of ocean temperatures around South Georgia, Southern Ocean: forcing by El Niño/southern oscillation and the southern annular mode. Deep Res Part II Top Stud Oceanogr 55:2007-2022. https://doi.org/10.1016/j.dsr2.2008.05.020

Murphy EJ, Watkins JL, Reid K, Trathan PN, Everson I, Croxall JP, Priddle J, Brandon MA, Brierley AS, Hofmann EE (1998) Interannual variability of the South Georgia marine ecosystem: biological and physical sources of variation in the abundance of krill. Fish Oceanogr 7:381-390. https://doi.org/10.104 6/j.1365-2419.1998.00081.x

Oksanen J, Guillaume Blanchet F, Friendly M, Kindt R, Legendre P, McGlinn D, Minchin PR, O'Hara RB, Simpson GL, Solymos P, Stevens MHH, Szoecs E, Wagner H (2019) vegan: community ecology package. R package version 2.5-4. https://CRAN.R-proje ct.org/package=vegan. Accessed April 2019

Paleczny M, Hammill E, Karpouzi V, Pauly D (2015) Population trend of the world 's monitored seabirds, 1950-2010. PLoS ONE 10:e0129342. https://doi.org/10.1371/journal.pone.0129342

Pardo D, Forcada J, Wood AG, Tuck GN, Ireland L, Pradel R, Croxall JP, Phillips RA (2017) Additive effects of climate and fisheries drive ongoing declines in multiple albatross species. Proc Natl Acad Sci USA 114:E10829-E10837. https://doi.org/10.1073/ pnas. 1618819114

Pauly D (1995) Anecdotes and the shifting baseline syndrome of fisheries. Trends Ecol Evol 10:430. https://doi.org/10.1016/S0169 -5347(00)89171-5

Phillips RA, Gales R, Baker GB, Double MC, Favero M, Quintana F, Tasker ML, Weimerskirch H, Uhart M, Wolfaardt A (2016) The conservation status and priorities for albatrosses and large petrels. Biol Conserv 201:169-183. https://doi.org/10.1016/j.bioco n.2016.06.017 
Piatt JF, Harding AMA, Shultz M, Speckman SG, van Pelt TI, Drew GS, Kettle AB (2007) Seabirds as indicators of marine food supplies: cairns revisited. Mar Ecol Prog Ser 352:221-234. https:// doi.org/10.3354/meps07072

Pocklington R (1979) An oceanographic interpretation of seabird distributions in the Indian Ocean. Mar Biol 51:9-21. https://doi. org/10.1007/BF00389026

Poloczanska ES, Burrows MT, Brown CJ, Molinos JG, Halpern BS, Hoegh-Guldberg O, Kappel CV, Moore PJ, Richardson AJ, Schoeman DS, Sydeman WJ (2016) Responses of marine organisms to climate change across oceans. Front Mar Sci 3:62. https://doi. org/10.3389/fmars.2016.00062

Poncet S, Wolfaardt AC, Black A, Browning S, Lawton K, Lee J, Passfield K, Strange D, Phillips RA (2017) Recent trends in numbers of wandering (Diomedea exulans), black-browed (Thalassarche melanophris) and grey-headed (T. chrysostoma) albatrosses breeding at South Georgia. Polar Biol 40:1347-1358. https://doi. org/10.1007/s00300-016-2057-0

Ribic CA, Ainley DG (1989) Constancy of seabird species assemblages: an exploratory look. Biol Oceanogr 6:175-202. https:// doi.org/10.1080/01965581.1988.10749526

Robertson G, Moreno C, Arata JA, Candy SG, Lawton K, Valencia J, Wienecke B, Kirkwood R, Taylor P, Suazo CG (2014) Blackbrowed albatross numbers in Chile increase in response to reduced mortality in fisheries. Biol Conserv 169:319-333. https://doi. org/10.1016/j.biocon.2013.12.002

Ryan PG (2018) Seabird conservation-a southern hemisphere perspective. Plenary lecture, 27th International Ornithological Congress, Vancouver

Silverman ED, Veit RR (2001) Associations among Antarctic seabirds in mixed-species feeding flocks. Ibis 143:51-62. https:// doi.org/10.1111/j.1474-919X.2001.tb04169.x

Silverman ED, Veit RR, Nevitt GA (2004) Nearest neighbors as foraging cues: information transfer in a patchy environment. Mar Ecol Prog Ser 277:25-35. https://doi.org/10.3354/meps277025

Smith RC, Fraser WR, Stammerjohn JE (2003) Climate variability and ecological response of the marine ecosystem in the western Antarctic Peninsula (WAP) region. In: Greenland D, Goodin D, Smith R (eds) Climate variability and ecosystem response at longterm ecological research sites. Oxford University Press, Oxford, pp 158-173

Stachowicz JJ (2001) Mutualism, facilitation, and the structure of ecological communities. Bioscience 51:235-246. https://doi. org/10.1641/0006-3568(2001)051[0235:MFATSO]2.0.CO;2

Sydeman WJ, Thompson SA, Santora JA, Koslow JA, Goericke R, Ohman MD (2015) Climate-ecosystem change off southern California: time-dependent seabird predator-prey numerical responses. Deep Sea Res Part II 112:158-170. https://doi.org/10.1016/j. dsr2.2014.03.008

Sydeman WJ, Thompson SA, Piatt JF, García-Reyes M, Zador S, Williams JC, Romano M, Renner HM (2017) Regionalizing indicators for marine ecosystems: Bering Sea-Aleutian Island seabirds, climate, and competitors. Ecol Indic 78:458-469. https://doi. org/10.1016/j.ecolind.2017.03.013

Tasker M, Jones PH, Dixon T, Blake BF (1984) Counting seabirds at sea from ships: a review of methods employed and a suggestion for a standardized approach. Auk 101:567-577. https://doi. org/10.2307/4086610

Terborgh J (1986) Keystone plant resources in the tropical forest. In: Soulé ME (ed) Conservation biology. Sinauer, Sunderland, pp 330-334

Thébault E, Fontaine C (2010) Stability of ecological communities and the architecture of mutualistic and trophic networks. Science 329:853-856. https://doi.org/10.1126/science.1188321

Thiebault A, Mullers R, Pistorius P, Meza-Torres MA, Dubroca L, Green D, Tremblay Y (2014) From colony to first patch: processes of prey searching and social information in Cape Gannets. Auk 131:595-609. https://doi.org/10.1642/AUK-13-209.1

Thiebault A, Semeria M, Lett C, Tremblay Y (2016) How to capture fish in a school? Effect of successive predator attacks on seabird feeding success. J Anim Ecol 85:157-167. https://doi. org/10.1111/1365-2656.12455

Thorpe WH (1956) Learning and instinct in animals. Methuen, London

Trathan PN, Ratcliffe N, Masden EA (2012) Ecological drivers of change at South Georgia: the krill surplus, or climate variability. Ecography 35:983-993. https://doi.org/10.111 1/j.1600-0587.2012.07330.x

Tremblay Y, Thiebault A, Mullers R, Pistorius P (2014) Bird-borne video-cameras show that seabird movement patterns relate to previously unrevealed proximate environment, not prey. PLoS ONE 9:e88424. https://doi.org/10.1371/journal.pone.0088424

Tuck GN, Polacheck T, Bulman CM (2003) Spatio-temporal trends of longline fishing effort in the Southern Ocean and implications for seabird bycatch. Biol Conserv 114:1-27. https://doi.org/10.1016/ S0006-3207(02)00378-6

Turner J, Lu H, White I, King JC, Phillips T, Hosking JS, Bracegirdle TJ, Marshall GJ, Mulvaney R, Deb P (2016) Absence of 21st century warming on Antarctic Peninsula consistent with natural variability. Nature 535:411-415. https://doi.org/10.1038/nature18645

Veit RR (1995) Pelagic communities of seabirds in the South Atlantic Ocean. Ibis 137:1-10. https://doi.org/10.1111/j.1474-919X.1995. tb03213.x

Veit RR, Harrison NM (2017) Positive interactions among foraging seabirds, marine mammals and fishes and implications for their conservation. Front Ecol Evol 5:121. https://doi.org/10.3389/ fevo.2017.00121

Veit RR, Hunt GL Jr (1991) Broadscale density and aggregation of pelagic birds from a circumnavigational survey of the Antarctic Ocean. Auk 180:790-800. https://doi.org/10.1093/auk/108.4.790

Veit RR, Manne LL (2015) Climate and changing winter distribution of alcids in the Northwest Atlantic. Front Ecol Evol 3:38. https:// doi.org/10.3389/fevo.2015.00038

Veit RR, McGowan JA, Ainley DG, Wahl TR, Pyle P (1997) Apex marine predator declines ninety percent in association with changing oceanic climate. Glob Change Biol 3:23-28. https:// doi.org/10.1046/j.1365-2486.1997.d01-130.x

Veit RR, Silverman ED, Everson I (1993) Aggregation patterns of pelagic predators and their principal prey, Antarctic krill, near South Georgia. J Anim Ecol 62:551-564. https://doi. org/10.2307/5204

Veit RR, Pyle P, McGowan JA (1996) Ocean warming and long-term change in pelagic bird abundance within the California current system. Mar Ecol Prog Ser 139:11-18. https://doi.org/10.3354/ meps 139011

Velarde E, Anderson DW, Ezcurra E (2019) Seabird clues to ecosystem health. Science 365:116-117. https://doi.org/10.1126/scien ce.aaw9999

Wahl TR, Ainley DG, Benedict AH, DeGange AR (1989) Associations between seabirds and water masses in the Northern Pacific Ocean in summer. Mar Biol 103:1-11. https://doi.org/10.1007/ BF00391059

Whitehouse MJ, Veit RR (1994) Distribution and abundance of seabirds and fur seals near the Antarctic Peninsula during the austral winter, 1986. Polar Biol 14:325-330. https://doi.org/10.1007/ BF00238448

Whitehouse MJ, Meredith MP, Rothery P, Atkinson A, Ward P, Korb RE (2008) Rapid warming of the ocean around South Georgia, Southern Ocean, during the 20th century: forcings, characteristics and implications for lower trophic levels. Deep Res Part I Oceanogr Res Pap 55:1218-1228. https://doi.org/10.1016/j. dsr.2008.06.002 
Winfree R, Williams NM, Dushoff J, Kremen C (2014) Species abundance, not diet breadth, drives the persistence of the most linked pollinators as plant-pollinator networks disassemble. Am Nat 183:600-611. https://doi.org/10.1086/675716
Zar JH (1999) Biostatical analysis, 5th edn. Prentice Hall, New Jersey, p 42

Publisher's Note Springer Nature remains neutral with regard to jurisdictional claims in published maps and institutional affiliations. 